\title{
From SARS to COVID-19: lessons we should have learned (but we did not)
}

\author{
Luciano Rodrigo Lopes' ${ }^{1}$ \\ João Henrique Campos² \\ Alison Felipe Alencar Chaves 3 (1)
}

${ }^{1}$ Corresponding author. Universidade Federal de São Paulo (São Paulo). São Paulo, Brazil. luciano.lopes@unifesp.br ${ }^{2}$ Universidade Federal de São Paulo (São Paulo). São Paulo, Brazil. joao.heima@gmail.com ${ }^{3}$ Instituto Butantan (São Paulo). São Paulo, Brazil. felipealison@gmail.com

ABSTRACT | In 2002, a severe acute respiratory (SARS) epidemic, caused by a coronavirus (SARS-CoV), affected a significant number of countries and was interrupted after one year approximately. Currently, coronavirus disease 2019 (COVID-19), caused by severe acute respiratory coronavirus 2 (SARS-CoV-2), has been a concern for the whole world, and the end of the pandemic does not appear near. In this article, we briefly discussed the lessons learned by the countries which fought the SARS epidemic and which had succeeded in controlling the COVID-19 pandemic. We also discussed some of the main points that resulted in failures to handle the coronavirus disease 2019 (COVID-19) pandemic. In the Brazilian context, we observed that the federal government delayed the necessary measures to be taken, has been less transparent to disclose health data, neglected the facemask usage mandates, and refused the COVID-19 vaccine offerings. Therefore, despite the previous coronavirus outbreaks, we are suffering during the COVID-19 pandemic because we did not learn about SARS.

KEYWORDS: Coronavirus. SARS. COVID-19. Pandemic. Brazil. Public Health. 


\section{Main text}

At the beginning of the century, in November 2002, a series of atypical pneumonia cases was reported in Heyuan, Guangdong Province, China. ${ }^{12}$ Later, these cases were named severe acute respiratory syndrome (SARS). A novel coronavirus (SARS-CoV) was identified in patients with SARS. ${ }^{3.4}$ Coronavirus RNA was found in the patient's sputum samples during the SARS acute phase. ${ }^{3,5}$ Feces, urine, and plasma presented coronavirus RNA during the convalescent phases ${ }^{5}$, which contributed to SARS-CoV transmission. SARSCoV spread rapidly on Chinese territory. ${ }^{-6}$ However, only in February 2003, the Chinese Health Department instituted mandatory case reporting of atypical pneumonia. ${ }^{1}$ Concomitantly, a series of public health control measures were applied, including clinical and epidemiological guidelines and infection control arrangements for patients. ${ }^{1}$

While the authorities from mainland China waited approximately two months to take proper measures to contain the SARS epidemic, the Hong Kong Department of Health implemented rigorous standards: made SARS a notifiable infectious disease starting from the first cases of SARS detected in Hong Kong; developed diagnostic testing; traced the source of SARS-CoV infection; strengthened collaboration and communication with the World Health Organization (WHO); promoted preventive education and publicity; and interrupted school and university classes.,, .8 Even when the epidemic began to slow down, the Hong Kong government increased the financial support for SARS-related research. -

Despite the relevant measures adopted by the Hong Kong government, the island presented the highest mortality (per million inhabitants) from all countries affected by SARS 9 back then. Nevertheless, during the COVID-19 (Coronavirus Disease 2019) pandemic, Hong Kong had 11,837 confirmed cases at the time of writing this piece, one of the lowest rates per million in developed countries (www.coronavirus.gov.hk). The Hong Kong experience with SARS appears to have prepared the country for new threats. Previous studies had already advised about the potential emergence of a new coronavirus disease due to SARS-like-CoV detection in various wild animals in China. 10,11
The SARS pandemic promoted a similar experience in Canada. The country created strategies to respond to future infectious disease threats. Consequently, Canada responded to the SARS-CoV-2 pandemic earlier, avoiding the health system's collapse because of the decreased morbimortality. ${ }^{12}$ Vietnam is another country where the SARS-CoV-2 had its spread curbed early on, and this is attributable to the early policy interventions adopted by the government. $\frac{13}{}$ Indeed, Vietnam formed a task force with clear critical directions for the population just one week after the first case detection. $\frac{14}{}$

Altogether, these historical facts point to the scenarios we should have been prepared for in Brazil, but we were not. COVID-19 pandemic hit countries like Brazil and the United States of America (USA), collapsing their health care services. At present, we can observe some critical points where we failed dramatically in response to the health crisis. Lawrence Gostin, director of the World Health Organization Center on National and Global Health Law, captured these points like the collapse of global solidarity, delayed health systems response, insufficient resources for WHO, lack of transparency in data communication, and, at the local level, a failure in coordinated national reactions..$^{15}$ These factors are interrelated and affect each other. At the beginning of the crisis, the USA president declared withdrawal from WHO, fragilizing the global capacity to respond to the pandemic at an international level. ${ }^{16}$ In line with this, WHO hesitated and delayed recommending broad usage of masks for the population. ${ }^{17,18}$

While the healthy population's facemask usage was controversial at the beginning of the COVID-19 pandemic, the Hong Kong community has adopted universal masking since the beginning of the pandemic. ${ }^{19}$ Comparing countries with wellstructured healthcare systems, where the community did not widely adopt facemask, the mask usage irrespective of symptoms has been shown to reduce the infectivity of COVID-19 cases to the susceptible individuals. ${ }^{19} \mathrm{~A}$ policy that establishes wide facemask usage all the time can reduce the COVID-19 RO from 2.2 to below one, even with facemask effectiveness at $50 \%$. ${ }^{20}$ The basic reproduction number or R0 can estimate the impact of the control of the epidemic. 
The R0 has been used to estimate the effectiveness of non-pharmaceutical interventions (NPI) adopted by governments. This is an epidemiologic metric representing the average number of infections produced by a single infectious person, an index in a population with no immunity. ${ }^{21,22}$ Therefore, $\mathrm{R} 0$ is an indicator of the contagiousness or transmissibility of infectious agents. Some factors that govern pathogen transmission can impact RO, such as numerous biological, socio-behavioral, and environmental conditions. $\frac{21}{1}$ To put this in perspective, if an infectious disease has an RO of 5, an infected individual will transmit it to an average of 5 other individuals. On a national scale, in May 2020, the estimated R0 for Brazil reached a median of 3.1. It was also slightly higher than R0 values estimated for other severely affected countries, such as Spain, France, and Italy. $\underline{\underline{23}}$

Brazil became the epicenter of the pandemic and not incidentally. Embarrassingly, president Jair Bolsonaro has taken decisions that actually have been impairing the economy and health of the population, ignoring scientific evidence. ${ }^{24,25}$ Despite the evidence discussed here, the President raised issues about face masks efficacy ${ }^{26}$ and rarely wears a mask at public events. Moreover, he declared that there is no scientific proof of the effectiveness of the lockdown and he has insisted on the narrative of pandemic curbing measures as attempts to harm the economy during his term in office.27 Consequently, the Brazilian president's antagonism led the National Supreme Court to establish that mayors and governors were autonomous in their decisions related to the COVID-19 pandemic. $\stackrel{28}{ }$ Nowadays, the impact of this federal centralized governmental omission is striking. Brazil has seen one of the highest case numbers of COVID-19 globally ${ }^{29}$, even though the disease is considered avoidable due to collective and individual preventive measures..$^{30}$

Indeed, evidence showed that NPI could reduce respiratory virus transmission, mitigate pandemics' consequences, and offer health services stability. 1,32 The NPI impact on the COVID-19 pandemic was reported in China ${ }^{33}$, across Europe ${ }^{34}$, and New Zealand. $\frac{35}{}$ The adoption of NPI reduced other respiratory diseases' incidence. ${ }^{36,37}$ Despite the evidence showing the successful measures taken by some countries during the pandemic, the Brazilian government waited for one year after the beginning of the pandemic to create the National Coordinating Committee to handle the crisis in March 2021. ${ }^{38}$
In April 2021, during the worst phase of COVID-19, preventive education and publicity to promote facemask usage were adopted by the Brazilian government ${ }^{39}$ after the requirement by the Public Ministry..$^{40}$ However, the Brazilian president refused to apply social distancing measures and other NP127,41 even after scientific advice showed its positive results in breaking the SARS-CoV-2 chain of transmission.

Sweden's government also chose to ignore scientific advice and kept political decisions during the COVID-19 pandemic in the Nordic countries' inverse direction. The Sweden Health Department decided to buy into herd immunity via natural infection ${ }^{42}$, a conceptual mistake with severe consequences. ${ }^{43}$ Consequently, Sweden presented an elevated incidence of SARS-CoV-2 infection with higher mortality than their neighbors. ${ }^{44}$ The other local governments reproduced the same error based on unauthorized conclusions from suboptimal studies. The Italian province of Bergamo ${ }^{45}$ and the Brazilian city of Manaus ${ }^{46}$ nurtured the false promise of herd immunity in the absence of a vaccine, which gave rise to a horrific scenario during the COVID-19 pandemic.

Consequently, the increased number of cases in Manaus, in Amazonas state, may have favored the emergence of the SARS-CoV-2 P.1 variant strain, which has presented a particularly dominant feature over other viral strains. ${ }^{47}$ SARS-CoV-2 P.1 strain is more transmissible and spawns a higher viral load than previous strains. ${ }^{47,48}$ It is not surprising that Amazonas has been the Brazilian state which presented the highest rate of accumulated cases of COVID-19 per million inhabitants. .9

Brazil has been presenting some of the highest records of deaths by COVID-19. According to the Johns Hopkins Coronavirus Resource Center ${ }^{29}$, Brazil has the second-highest mortality rate globally, accumulating 422,340 deaths by COVID-19 at the time of writing this piece. Although the Brazilian population is equivalent to $2.73 \%$ of the total world population, the deaths by COVID-19 in Brazil encompass $12.97 \%$ of deaths in the world. Epidemiological studies showed the potential underreporting of deaths by COVID-19 in Brazil. $.0,51$ There was an increase of unexpected deaths by natural causes in regions severely inflicted by COVID-19. 50,51 The excess of deaths can be associated with indirect consequences of the COVID-19 pandemic, such as health care shortages or overburdened health care systems. $\underline{52}$ 
However, although the number of elective surgeries decreased $34 \%$ in 2020, the urgent procedures decreased only $1.1 \% . \underline{53}$ Life-saving procedures offered by the Brazilian public health system, such as cancer treatment and urgent surgeries, suffered minor reductions during the COVID-19 pandemic. ${ }^{53}$ Therefore, the Brazilian underreporting of severe patients affected by COVID-19 may be associated with the lack of the SARS-CoV-2 screening by RTPCR (reverse transcriptase-polymerase chain reaction). While the rate of fatalities by COVID-19 has increased, Brazil carries the lowest number of tests for coronavirus diagnosis per million inhabitants. ${ }^{49}$ The northern states of Brazil presented the highest percentages of unexpected deaths by natural causes 50 and had the lowest availability for RT-PCR tests and intensive care units. 50,54

Collecting and analyzing data related to COVID-19 provide a set of indicators favoring planned actions against pandemic. $\frac{55}{5}$ For instance, the mortality rate is a strategic indicator recommended by the WHO to assess the effects of the COVID-19 pandemic. $\frac{56}{6}$ However, Brazil is highlighted as less transparent regarding the COVID-19 management, according to the TotalAnalysis initiative, a UK independent research group aiming to report pandemic data (https://www. totalanalysis.com/Covid19/TAIndex). ${ }^{57}$ In this context, Brazil formed a collaborative Consortium of Press Journalists to collect health data from the states of the Brazilian Republic in response to the Bolsonaro government's decision to restrict access to data COVID-19 pandemic. Sharing data and transparency are critical factors to make informed decisions on early interventions during a global health crisis. The TotalAnalysis index ranked Belgium, Norway, the USA, Chile, and Denmark as the most transparent in communicating data (Covid Data Transparency Index: 75\%). ${ }^{57}$ On the other hand, Turkmenistan and North Korea scored 0\% transparency. India scored 33\%, Brazil $25 \%$, and China $17 \%$ transparency. ${ }^{57}$ The data behind medical research needs to be public, as evidenced by the case of Surgisphere $\frac{58}{}$, and the epidemiological data collected by governmental institutions also must be public. Open public databases developed during the pandemic have helped understand the infections' scale up, but the data source remains limited. $\underline{.} \underline{9}$

As the cases grew, the Brazilian president expressed contempt for the vulnerable population and preferred to ignore the disease's lethality. .0 Since this behavior reveals to be harmful to the people, the impact of any unified message transmitting recommendations to the public is impaired. The divergent perspective of president Bolsonaro is critical to promote widespread populational resistance in adopting safety behaviors, such as facemask usage and social distancing, a phenomenon defined by $\mathrm{WHO}$ as pandemic fatigue. ${ }^{61}$ Beyond the fatigue, there is the impact of political discourse, which split people into ideological groups. The missing of a unified message concerned with social welfare during the health crisis is associated with population's risk behaviors. .2.63 $^{2}$

While the Brazilian population suffers due to the lack of efficient measures to control the COVID-19 pandemic, in the past, successful efforts were taken by the Brazilian government in the global fight against AIDS (universal accession to antiretroviral drugs, massive population-level testing, needle-exchange programs and free condoms availability). ${ }^{64,65}$ During the Zika virus outbreak, the Brazilian Health Department took adequate measures and considered the scientific alerts. ${ }^{6}$ Moreover, the Brazilian National Immunization Program provides an important reduction in cases and deaths from vaccine-preventable diseases, offering the most vaccines free of cost to the population. . $^{-7}$ On the other hand, the initiatives against COVID-19 were neglected, interrupting the traditional capacity of the Brazilian health system to raise to public health challenges. Despite the success of the National Immunization Program over the last decades, Brazil has presented problems in conducting the vaccination against SARS-CoV-2. President Bolsonaro repeatedly ignored the Pfizer-BioNTech COVID-19 vaccine offerings in September 2020, whereas the USA acquired 100 million doses of Pfizer-BioNTech COVID-19 vaccines in the same period. ${ }^{68}$ Consequently, in May 2021, only $20.3 \%$ of the Brazilian population (or 43,24 millions of people partially immunized) received at least one dose of the anti-COVID-19 vaccine. ${ }^{69}$ Thus, $39 \%$ of the population of the USA have been fully vaccinated, encompassing 131,85 millions of people. .99

The failures in maintaining NPI, giving support to vulnerable populations, and offering vaccination were partly responsible for the rise of variants of concern, like P.1, B.1.1.7, and B.1.351. There is a concern that these variants could evade the immune response and cause more severe disease, though the debate is not settled. $\frac{70,71}{\text { We know }}$ that SARS-CoV and SARS-CoV-2 undergo frequent recombination, which can be responsible for the spillover event and the rise of new variants. $.2-74$ 
Variability of SARS-CoV-2 could affect the efficiency of antibody neutralization elicited by vaccination, which would then need to be updated with new viral variants. $\frac{70}{}$ Then, the broad vaccination could decrease the number of susceptible individuals and reduce the opportunities of SARS-CoV-2 to spread and mutate.

Although the COVID-19 pandemic has surprised the whole world, numerous alerts have been given by the scientific community after the coronavirus outbreaks in the past decades (SARS and Middle East respiratory syndrome - MERS). Therefore, we should have been better prepared to deal with the COVID-19 pandemic at a national level in Brazil. The Brazilian Constitution mandates that healthcare is a national prerogative, which means that the federal government has failed its people. Led by Jair Bolsonaro, the government avoided fighting the pandemic and clearly neglected the measures recommended by $\mathrm{WHO}$ and scientific leadership. The political choices of President Bolsonaro favor viral transmission to re-establish economic activities as quickly as possible, as discussed in a previous study. ${ }^{75}$ Thus, the lack of actions and measures from the Brazilian government and public health has been shown to increase the lethality of an epidemic. While public health authorities do not make evidence-informed decisions to control it in Brazil, the front-line staff will remain unprepared, and the epidemiologic control may be ineffective. Moreover, considering the high transmissibility of SARS-CoV-2 and the other coronavirus, the absence of effective actions to control the transmissions, even for a few days, can result in disastrous scenarios. Finally, as long as Brazil is unable to assimilate the lessons given by history or by successful experiences of countries that correctly anticipated the real threat posed by this pandemic, we will still suffer due to the consequences of wrong decision-making during the ongoing public health crisis.

\section{Acknowledgments}

The authors thank Mr. Vitor Machado Tonini for text revision. Especial thanks to Health Informatics Department and Universidade Federal de São Paulo - Unifesp for all the support.

\section{Author contributions}

All authors conceived, wrote, revised, and approved the final version of this report.

\section{Competing interests}

No financial, legal or political competing interests with third parties (government, commercial, private foundation, etc.) were disclosed for any aspect of the submitted work (including but not limited to grants, data monitoring board, study design, manuscript preparation, statistical analysis, etc.).

\section{References}

1. Xu R-H, He J-F, Evans MR, Peng G-W, Field HE, Yu D-W, et al. Epidemiologic clues to SARS origin in China. Emerg Infect Dis. 2004;10(6):1030-7. https://doi.org/10.3201/eid1006.030852

2. Kumar M, Taki K, Gahlot R, Sharma A, Dhangar K. A chronicle of SARS-CoV-2: Part-I - Epidemiology, diagnosis, prognosis, transmission and treatment. Sci Total Environ. 2020;734:139278. https://doi.org/10.1016/j.scitotenv.2020.139278

3. Drosten C, Günther S, Preiser W, van der Werf S, Brodt $\mathrm{H}-\mathrm{R}$, Becker $\mathrm{S}$, et al. Identification of a novel coronavirus in patients with severe acute respiratory syndrome. N Engl J Med. 2003;348(20):1967-76. https://doi.org/10.1056/nejmoa030747

4. Peiris JSM, Lai ST, Poon LLM, Guan Y, Yam LYC, Lim W, et al. Coronavirus as a possible cause of severe acute respiratory syndrome. Lancet Lond Engl. 2003;361(9366):1319-25. https://doi. org/10.1016/s0140-6736(03)13077-2

5. Xu D, Zhang Z, Jin L, Chu F, Mao Y, Wang H, et al. Persistent shedding of viable SARS-CoV in urine and stool of SARS patients during the convalescent phase. Eur J Clin Microbiol Infect Dis Off Publ Eur Soc Clin Microbiol. 2005;24(3):165-71. https://doi. org/10.1007/s10096-005-1299-5

6. Feng D, De Vlas SJ, Fang L-Q, Han X-N, Zhao W-J, Sheng S, et al. The SARS epidemic in mainland China: bringing together all epidemiological data. Trop Med Int Health TM IH. 2009;14(Suppl 1):4-13. https://doi.org/10.1111/j.1365-3156.2008.02145.x

7. Tsang T, Lam T. SARS: public health measures in Hong Kong. Respirology. 2003;8(s1):S46-8. https://doi.org/10.1046/j.14401843.2003.00524.x

8. Hung LS. The SARS epidemic in Hong Kong: what lessons have we learned? J R Soc Med. 2003 Aug;96(8):374-8. Cited: PMID: PMID: 12893851

9. Leung GM, Hedley AJ, Ho L-M, Chau P, Wong IOL, Thach TQ, et al. The epidemiology of severe acute respiratory syndrome in the 2003 Hong Kong epidemic: an analysis of all 1755 patients. Ann Intern Med. 2004;141(9):662-73. https://doi.org/10.7326/00034819-141-9-200411020-00006 
10. Guan Y, Zheng BJ, He YQ, Liu XL, Zhuang ZX, Cheung CL, et al. Isolation and characterization of viruses related to the SARS coronavirus from animals in southern China. Science. 2003;302(5643):276-8. https://doi.org/10.1126/science.1087139

11. Lau SKP, Woo PCY, Li KSM, Huang Y, Tsoi H-W, Wong BHL, et al. Severe acute respiratory syndrome coronavirus-like virus in Chinese horseshoe bats. Proc Natl Acad Sci U S A. 2005;102(39):14040-5. https://doi.org/10.1073/pnas.0506735102

12. Silverman M, Clarke M, Stranges S. Did Lessons From SARS Help Canada's Response to COVID-19? Am J Public Health. 2020;110(12):1797-9. https://doi.org/10.2105/ajph.2020.305936

13. Van Nguyen Q, Cao DA, Nghiem SH. Spread of COVID-19 and policy responses in Vietnam: An overview. Int J Infect Dis IJID Off Publ Int Soc Infect Dis. 2021;103:157-61. https://doi.org/10.1016/j. ijid.2020.11.154

14. Ha BTT, Ngoc Quang L, Mirzoev T, Tai NT, Thai PQ, Dinh PC. Combating the COVID-19 Epidemic: Experiences from Vietnam. Int J Environ Res Public Health. 2020;17(9). https://doi.org/10.3390/ ijerph17093125

15. Gostin LO. The Coronavirus Pandemic 1 Year On-What Went Wrong? JAMA. 2021;325(12):1132-3. https://doi.org/10.1001/ jama.2021.3207

16. Gostin LO, Koh HH, Williams M, Hamburg MA, Benjamin $\mathrm{G}$, Foege WH, et al. US withdrawal from WHO is unlawful and threatens global and US health and security. Lancet Lond Engl. 2020;396(10247):293-5. https://doi.org/10.1016/s01406736(20)31527-0

17. Howard J. WHO stands by recommendation to not wear masks if you are not sick or not caring for someone who is sick [Internet]. CNN. [cited 2021 May 12]. Available from: https:// www.cnn.com/2020/03/30/world/coronavirus-who-masksrecommendation-trnd/index.html

18. WHO. Advice on the use of masks in the community, during home care and in healthcare settings in the context of the novel coronavirus (COVID-19) outbreak [Internet]. 2020 [cited 2021 May 12]. Available from: https://www.who.int/publications-detailredirect/advice-on-the-use-of-masks-in-the-community-duringhome-care-and-in-healthcare-settings-in-the-context-of-the-novelcoronavirus-(2019-ncov)-outbreak

19. Cheng VC-C, Wong S-C, Chuang VW-M, So SY-C, Chen JH-K, Sridhar $\mathrm{S}$, et al. The role of community-wide wearing of face mask for control of coronavirus disease 2019 (COVID-19) epidemic due to SARS-CoV-2. J Infect. 2020;81(1):107-14. https://doi. org/10.1016/j.jinf.2020.04.024

20. Stutt ROJH, Retkute R, Bradley M, Gilligan CA, Colvin J. A modelling framework to assess the likely effectiveness of facemasks in combination with "lock-down" in managing the COVID-19 pandemic. Proc Math Phys Eng Sci.

2020;476(2238):20200376. https://doi.org/10.1098/rspa.2020.0376
21. Delamater PL, Street EJ, Leslie TF, Yang YT, Jacobsen KH. Complexity of the Basic Reproduction Number (R0). Emerg Infect Dis. 2019;25(1):1-4. https://doi.org/10.3201/eid2501.171901

22. Bauch CT. Estimating the COVID-19 R number: a bargain with the devil? Lancet Infect Dis. 2021;21(2):151-3. https://doi. org/10.1016/s1473-3099(20)30840-9

23. Souza WM, Buss LF, Candido DS, Carrera J-P, Li S, Zarebski AE, et al. Epidemiological and clinical characteristics of the COVID-19 epidemic in Brazil. Nat Hum Behav. 2020;4(8):856-65. https://doi. org/10.1038/s41562-020-0928-4

24. Ponce D. The impact of coronavirus in Brazil: politics and the pandemic. Nat Rev Nephrol. 2020;16(9):483. https://doi. org/10.1038/s41581-020-0327-0

25. Simões E, Paraguassu L. Brazil business elite blast Bolsonaro, who remains unconvinced on COVID-19 restrictions. Reuters [Internet]. 2021 [cited 2021 May 12]; Available from: https://www. reuters.com/article/us-health-coronavirus-brazil-idUSKBN2BE1ND

26. Krüger A. Em dia de recorde de mortes, Bolsonaro questiona o uso de máscaras [Internet]. Congresso em Foco. 2021 [cited 2021 Jul 22]. Available from: https://congressoemfoco.uol.com.br/ governo/em-dia-de-recorde-de-mortes-bolsonaro-questiona-ouso-de-mascaras/

27. Discurso do Presidente da República, Jair Bolsonaro, na Cerimônia de Entrega de Títulos de Propriedade Rural no Estado do Mato Grosso do Sul - Português (Brasil) [Internet]. Presidência da Republica. 2021 [cited 2021 Jul 19]. Available from: https://www.gov.br/planalto/pt-br/acompanhe-o-planalto/ discursos/2021/discurso-do-presidente-da-republica-jairbolsonaro-na-cerimonia-de-entrega-de-titulos-de-propriedaderural-no-estado-do-mato-grosso-do-sul

28. Supremo Tribunal Federal. STF reconhece competência concorrente de estados, DF, municípios e União no combate à Covid-19 [Internet]. Supremo Tribunal Federal. [cited 2021 May 12]. Available from: http://portal.stf.jus.br/noticias/ verNoticiaDetalhe.asp?idConteudo $=441447 \&$ ori $=1$

29. Dong E, Du H, Gardner L. An interactive web-based dashboard to track COVID-19 in real time. Lancet Infect Dis. 2020;20(5):533-4. https://doi.org/10.1016/s1473-3099(20)30120-1

30. Fraser C, Riley S, Anderson RM, Ferguson NM. Factors that make an infectious disease outbreak controllable. Proc Natl Acad Sci U S A. 2004;101(16):6146-51. https://doi.org/10.1073/ pnas. 0307506101

31. Markel H, Lipman HB, Navarro JA, Sloan A, Michalsen JR, Stern AM, et al. Nonpharmaceutical interventions implemented by US cities during the 1918-1919 influenza pandemic. JAMA. 2007;298(6):644-54. https://doi.org/10.1001/jama.298.6.644 
32. Liang M, Gao L, Cheng C, Zhou Q, Uy JP, Heiner K, et al. Efficacy of face mask in preventing respiratory virus transmission: $\mathrm{A}$ systematic review and meta-analysis. Travel Med Infect Dis. 2020;36:101751. https://doi.org/10.1016/j.tmaid.2020.101751

33. Lai S, Ruktanonchai NW, Zhou L, Prosper O, Luo W, Floyd $J R$, et al. Effect of non-pharmaceutical interventions to contain COVID-19 in China. Nature. 2020;585(7825):410-3. https://doi. org/10.1038/s41586-020-2293-x

34. Flaxman S, Mishra S, Gandy A, Unwin HJT, Mellan $T A$, Coupland $H$, et al. Estimating the effects of nonpharmaceutical interventions on COVID-19 in Europe. Nature. 2020;584(7820):257-61. https://doi.org/10.1038/s41586-020-2405$\underline{7}$

35. Huang QS, Wood T, Jelley L, Jennings T, Jefferies S, Daniells K, et al. Impact of the COVID-19 nonpharmaceutical interventions on influenza and other respiratory viral infections in New Zealand. Nat Commun. 2021;12(1):1001. https://doi.org/10.1038/s41467021-21157-9

36. Huh K, Jung J, Hong J, Kim M, Ahn JG, Kim J-H, et al. Impact of Nonpharmaceutical Interventions on the Incidence of Respiratory Infections During the Coronavirus Disease 2019 (COVID-19) Outbreak in Korea: A Nationwide Surveillance Study. Clin Infect Dis Off Publ Infect Dis Soc Am. 2021;72(7):e184-91. https://doi. org/10.1093/cid/ciaa1682

37. Cowling BJ, Ali ST, Ng TWY, Tsang TK, Li JCM, Fong MW, et al. Impact assessment of non-pharmaceutical interventions against coronavirus disease 2019 and influenza in Hong Kong: an observational study. Lancet Public Health. 2020;5(5):e279-88. https://doi.org/10.1016/s2468-2667(20)30090-6

38. Brasil. Governo Federal cria Comitê de Combate à COVID-19 [Internet]. Secretaria de Governo. 2021 [cited 2021 May 12]. Available from: https://www.gov.br/secretariadegoverno/pt-br/ assuntos/noticias/ultimas-noticias-1/governo-federal-e-congressonacional-criam-comite-de-combate-a-covid-19

39. Brasil. Coronavírus: Ministério da Saúde lança campanha de prevenção [Internet]. Governo do Brasil. 2021 [cited 2021 May 12]. Available from: https://www.gov.br/pt-br/noticias/saude-evigilancia-sanitaria/2020/03/coronavirus-ministerio-da-saudelanca-campanha-de-prevencao

40. Justiça Federal do Rio Grande do Sul. Justiça Federal determina que União apresente Plano Nacional de Comunicação para enfrentar pandemia [Internet]. 2021 [cited 2021 May 12]. Available from: https://www2.jfrs.jus.br/noticias/justica-federaldetermina-que-uniao-apresente-plano-nacional-de-comunicacaopara-enfrentar-pandemia/

41. Brasil. Derrubado veto de Bolsonaro ao uso obrigatório de máscara na pandemia [Internet]. Senado Federal. [cited 2021 Jul 22]. Available from: https://www12.senado.leg.br/noticias/ materias/2020/08/19/derrubado-veto-de-bolsonaro-ao-usoobrigatorio-de-mascara-na-pandemia
42. Habib H. Has Sweden's controversial covid-19 strategy been successful? BMJ. 20202;369:m2376. https://doi.org/10.1136/bmj. $\underline{\mathrm{m} 3255}$

43. Aschwanden C. The false promise of herd immunity for COVID-19. Nature. 2020;587(7832):26-8. https://doi.org/10.1038/ d41586-020-02948-4

44. Claeson M, Hanson S. COVID-19 and the Swedish enigma. Lancet Lond Engl. 2021;397(10271):259-61. https://doi. org/10.1016/s0140-6736(20)32750-1

45. Signorelli C, Zucchi A, Tersalvi CA, Ciampichini R, Beato E, Balzarini F, et al. High seroprevalence of SARS_COV-2 in Bergamo: evidence for herd immunity or reason to be cautious? Int J Public Health. 2020;65(9):1815-7. https://doi.org/10.1007/s00038-02001524-x

46. Buss LF, Prete CA, Abrahim CM, Mendrone A, Salomon T, Almeida-Neto C, et al. COVID-19 herd immunity in the Brazilian Amazon. medRxiv. 2020 S;2020.09.16.20194787. https://doi. org/10.1101/2020.09.16.20194787

47. Faria NR, Mellan TA, Whittaker C, Claro IM, Candido DS, Mishra $\mathrm{S}$, et al. Genomics and epidemiology of the P.1 SARS-CoV-2 lineage in Manaus, Brazil. Science. 2021;372(6544):815-21. https://doi. org/10.1126/science.abh2644

48. Naveca F, Nascimento V, Souza V, Corado A, Nascimento F, Silva G, et al. COVID-19 epidemic in the Brazilian state of Amazonas was driven by long-term persistence of endemic SARSCoV-2 lineages and the recent emergence of the new Variant of Concern P.1 [Internet]. In Review; 2021 Feb [cited 2021 May 12]. Available from: https://www.researchsquare.com/article/rs275494/v1

49. Melo GC, Duprat IP, Araújo KCGM, Fischer FM, Araújo Neto RA. Prediction of cumulative rate of COVID-19 deaths in Brazil: a modeling study. Rev Bras Epidemiol Braz J Epidemiol. 2020;23:e200081. https://doi.org/10.1590/1980-549720200081

50. Carvalho TA, Boschiero MN, Marson FAL. COVID-19 in Brazil: 150,000 deaths and the Brazilian underreporting. Diagn Microbiol Infect Dis. 2021;99(3):115258. https://doi.org/10.1016/j. diagmicrobio.2020.115258

51. Orellana JDY, Cunha GM, Marrero L, Moreira RI, Leite IC, Horta BL. Excess deaths during the COVID-19 pandemic: underreporting and regional inequalities in Brazil. Cad Saúde Pública. 2021;37:e00259120. https://doi.org/10.1590/0102-311X00259120

52. CDC - Centers for Disease Control and Prevention. Excess Deaths Associated with COVID-19 [Internet]. 2021 [cited 2021 Jul 21]. Available from: https://www.cdc.gov/nchs/nvss/vsrr/covid19/ excess deaths.htm

53. Luizeti BO, Perli VAS, Costa GG, Eckert IC, Roma AM, Costa KM. Impact of the COVID-19 pandemic on surgical procedures in Brazil: a descriptive study. medRxiv. 2021;2021.03.17.21253801. https://doi.org/10.1101/2021.03.17.21253801 
54. Palamim CVC, Marson FAL. COVID-19 - The Availability of ICU Beds in Brazil during the Onset of Pandemic. Ann Glob Health. 2020;86(1):100. https://dx.doi.org/10.5334\%2Faogh.3025

55. WHO. Monitoring and evaluation framework [Internet]. 2020 [cited 2021 May 12]. Available from: https://www.who.int/ publications-detail-redirect/monitoring-and-evaluation-framework

56. WHO. Estimating mortality from COVID-19: Scientific brief, 4 August 2020 [Internet]. 2020 [cited 2021 May 12]. Available from: https://www.who.int/publications-detail-redirect/WHO-2019nCoV-Sci-Brief-Mortality-2020.1

57. TotalAnalysis [Internet]. [cited 2021 Jul 19]. Available from: https://www.totalanalysis.com/Covid19/TAlndex

58. The Lancet Digital Health. Transparency during global health emergencies. Lancet Digit Health. 2020;2(9):e441. https://dx.doi. org/10.1016\%2FS2589-7500(20)30198-9

59. Gardner L, Ratcliff J, Dong E, Katz A. A need for open public data standards and sharing in light of COVID-19. Lancet Infect Dis. 2021;21(4):e80. https://doi.org/10.1016/s1473-3099(20)30635-6

60. The Lancet. COVID-19 in Brazil: "So what?" Lancet Lond Engl. 2020;395(10235):1461. https://doi.org/10.1016/s01406736(20)31095-3

61. Crane MA, Shermock KM, Omer SB, Romley JA. Change in Reported Adherence to Nonpharmaceutical Interventions During the COVID-19 Pandemic, April-November 2020. JAMA. 2021;325(9):883-5. https://pubmed.ncbi.nlm.nih.gov/33480971/

62. Green J, Edgerton J, Naftel D, Shoub K, Cranmer SJ. Elusive consensus: Polarization in elite communication on the COVID-19 pandemic. Sci Adv. 2020;6(28):eabc2717. https://dx.doi. org/10.1126\%2Fsciadv.abc2717

63. Bekalu MA, Dhawan D, McCloud R, Pinnamaneni R, Viswanath K. Adherence to COVID-19 mitigation measures among American adults: the need for consistent and unified messaging. Health Educ Res. 2021;36(2):178-91. https://dx.doi. org/10.1093\%2Fher\%2Fcyab002

64. Villarinho MV, Padilha MI, Berardinelli LMM, Borenstein MS, Meirelles BHS, Andrade SR de. Public health policies facing the epidemic of AIDS and the assistance for people with the disease. Rev Bras Enferm. 2013;66(2):271-7. https://pubmed.ncbi.nlm.nih. gov/23743849/

65. Okie S. Fighting HIV — Lessons from Brazil. N Engl J Med. 2006;354(19):1977-81. https://doi.org/10.1056/nejmp068069
66. Lowe R, Barcellos C, Brasil P, Cruz OG, Honório NA, Kuper H, et al. The Zika Virus Epidemic in Brazil: From Discovery to Future Implications. Int J Environ Res Public Health. 2018;15(1):96. https:// pubmed.ncbi.nlm.nih.gov/29315224/

67. Domingues CMAS, Maranhão AGK, Teixeira AM, Fantinato FFS, Domingues RAS. The Brazilian National Immunization Program: 46 years of achievements and challenges. Cad Saude Publica. 2020;36 (Suppl 2):e00222919. https://doi.org/10.1590/0102$\underline{311 \times 00222919}$

68. Junqueira C. Em carta, CEO mundial da Pfizer pediu a Bolsonaro pressa na compra de vacinas [Internet]. CNN Brasil. 2021 [cited 2021 May 12]. Available from: https://www.cnnbrasil. com.br/nacional/2021/01/22/em-carta-ceo-mundial-da-pfizerpediu-a-bolsonaro-pressa-na-compra-de-vacinas

69. Ritchie H, Ortiz-Ospina E, Beltekian D, Mathieu E, Hasell J, Macdonald B, et al. Coronavirus Pandemic (COVID-19). Our World Data [Internet]. 2020 [cited 2021 Jul 19]; Available from: https:// ourworldindata.org/covid-vaccinations

70. Altmann DM, Boyton RJ, Beale R. Immunity to SARS-CoV-2 variants of concern. Science. 2021;371(6534):1103-4. https://doi. org/10.1126/science.abg7404

71. Frampton D, Rampling T, Cross A, Bailey H, Heaney J, Byott $M$, et al. Genomic characteristics and clinical effect of the emergent SARS-CoV-2 B.1.1.7 lineage in London, UK: a wholegenome sequencing and hospital-based cohort study. Lancet Infect Dis. 2021;21(9):1246-56. https://doi.org/10.1016/S14733099(21)00170-5

72. Boni MF, Lemey P, Jiang X, Lam TT-Y, Perry BW, Castoe TA, et al. Evolutionary origins of the SARS-CoV-2 sarbecovirus lineage responsible for the COVID-19 pandemic. Nat Microbiol. 2020;5(11):1408-17. https://doi.org/10.1038/s41564-020-0771-4

73. Li X, Giorgi EE, Marichannegowda MH, Foley B, Xiao C, Kong $X-P$, et al. Emergence of SARS-CoV-2 through recombination and strong purifying selection. Sci Adv. 2020;6(27). https://dx.doi. org/10.1101\%2F2020.03.20.000885

74. Shahhosseini N, Wong G, Kobinger GP, Chinikar S. SARSCoV-2 spillover transmission due to recombination event. Gene Rep. 2021;23:101045. https://dx.doi.org/10.1016\%2Fj. genrep.2021.101045

75. Ventura D, Reis R. An unprecedented attack on human rights in Brazil: the timeline of the federal government's strategy to spread Covid-19. Offprint. Translation by Luis Misiara, revision by Jameson Martins. Bulletin Rights in the Pandemic n. 10, São Paulo, Brazil, CEPEDISA/USP and Conectas Human Rights [Internet]. Conectas. 2021 [cited 2021 Jul 22]. Available from: https://www. conectas.org/publicacao/boletim-direitos-na-pandemia-no-10/ 